\title{
Characterization of epidermal growth factor receptor in testis, epididymis and vas deferens of non-human primates
}

\author{
B. Radhakrishnan and C. A. Suarez-Quian* \\ Georgetown University School of Medicine, Department of Anatomy and Cell Biology, \\ 3900 Reservoir Road, NW, Washington, DC 20007, USA
}

\begin{abstract}
Summary. The presence of the epidermal growth factor receptor (EGFR) in testis, epididymis and vas deferens of monkeys was demonstrated using a polyclonal antibody (RK2) raised against a peptide-specific sequence of the intracellular domain of the human EGFR. Immunoblotting of membrane preparations revealed a specific band at approximately $170 \mathrm{kDa}$ corresponding to those of controls, A431 and monkey liver cells. Cryostat sections were stained by biotin-streptavidin peroxidase immunocytochemistry. The liver showed positive staining along the basolateral membranes of the hepatocytes lining the sinusoids. The testis showed positive staining indicating the presence of EGFR in Leydig cells, Sertoli cells and peritubular cells. In the epididymis, immunostaining of the EGFR was observed on both the basolateral and the luminal borders of the epididymal epithelium. Immunofluorescence studies revealed a similar pattern of EGFR distribution in the epididymis and indicated that the luminal immunostaining was vesicular. In the vas deferens, positive immunostaining was detected in a pattern very similar to that observed in the epididymis. There was no positive staining in the interstitium of the epididymis or in the smooth muscle cell layers of the vas deferens. The sections of all tissues treated with pre-immune serum were negative. These results suggest that EGF in the primate testis may act at the level of somatic cells. In addition, the basolateral and luminal EGFR staining in the epididymis and vas deferens suggest that these cells respond to an EGF, or EGF-like, source both at the basal, luminal or at both sides of the cells, or that these tissues serve as sites of EGF transcytosis across the epithelium.
\end{abstract}

Kelkords: EGF receptors; spermatogenesis; immunocytochemistry; monkey; testis

\section{Introduction}

Growth factors are likely to take part in the regulation of spermatogenesis, working possibly in a paracrine or autocrine fashion within the testis (reviewed by Bellve \& Zheng, 1989; Skinner, 1991). Epidermal growth factor (EGF) has elicited much interest regarding its potential effects on spermatogenesis. For example, sialoadenectomy of adult male mice led to the elimination of circulating plasma EGF (measured by radioimmunoassay), without a concomitant decrease in gonadotrophin and androgen concentrations and caused a marked decrease in male fertility (Tsutsumi et al., 1986). Replacement therapy with EGF reversed the deleterious effects of sialoadenectomy on male fertility. Recent studies have been able to corroborate, in part, these findings (Russell et al., 1990; Seethalakshimi et al., 1991). Further, in experimentally induced diabetic mice that exhibit EGF deficiency that leads to the pathogenesis of oligozoospermia, daily administration of EGF significantly increased the number of spermatozoa (Noguchi et al., 1990). In addition, functional studies of both Leydig cells (Ascoli, 1981; Welsh \& Hsueh, 1982; Bernier et al.,

*Reprint requests. 
1986; Verhoeven \& Cailleau, 1986) and Sertoli cells (Mallea et al., 1986; Smith et al., 1987; Morris et al., 1988) in vitro have elucidated potential mechanisms of EGF action on spermatogenesis. Taken together, these studies suggest that EGF could act directly on the testis to bring about its effects on spermatogenesis.

Epidermal growth factor exerts its biological effects through a specific $170 \mathrm{kDa}$ transmembrane protein, the EGF receptor (reviewed in Ullrich et al., 1984; Schlessinger, 1986; Gill et al., 1987; Carpenter, 1987). The site of action of EGF in rodent testes was shown by immunocytochemical localization of the EGF receptor to be Sertoli cells and Leydig cells in rats and mice (Suarez-Quian et al., 1989; Suarez-Quian \& Niklinski, 1990). Similar investigations in the male reproductive tract of non-human primates would lead to a better understanding of the process by which spermatogenesis is regulated by EGF and may provide insight into new avenues of studies for fertility and infertility control in man, as well as the role that EGF may play in testicular development. For example, EGF was shown to be associated with synchronizing the onset of spermatogenesis in rats (Bartlett et al., 1990) and a recent study reported changes in the concentration of EGF receptor mRNA in testes of monkeys approaching puberty (Keeping, 1991). We report here the presence and distribution pattern of EGF receptors in testis, epididymis and vas deferens of monkeys by immunoblotting and immunocytochemical methods.

\title{
Materials and Methods
}

\section{Animals and treatments}

Tissues used in this study, testis, epididymis, vas deferens and liver, from pubertal and adult monkeys (Macaca fascicularis, M. cynomolgus and Papio cynocephalus) were obtained from the Regional Primate Research Centre, University of Washington (supported by NIH Grant RR00166) and the Research Resources Facility, Georgetown University. Tissues were immediately flash frozen in liquid nitrogen.

\begin{abstract}
Antibody
The antibody used in this study, RK2, was raised against a carboxy-terminus sequence (DVVDADEYLIPQ) that corresponds to residues 984-996 of the intracellular domain of the human EGF receptor (Kris et al., 1985) and was a generous gift of F. Bellot (Rhone-Poulenc Rorer Central Research, Horsham, PA). This antibody was used for both immunoblotting and immunostaining methods. The validity of RK2 as an antibody probe for the EGF receptor of a broad range of species, including mice, rats, humans and chickens, was documented recently (Bellot et al., 1990).
\end{abstract}

\section{Cell culture}

A431 cell lines, obtained from the American Type Culture Collection were cultured in Dulbeco's Modified Eagle's Medium plus $10 \%$ bovine calf serum, containing $1.2 \mathrm{~g}$ sodium bicarbonate $\mathrm{l}^{-1}, 15 \mathrm{mmol} \mathrm{Hepes} \mathrm{I}^{-1}$ and $4.5 \mathrm{~g}$ glucose $\mathrm{I}^{-1}$, $20 \mu \mathrm{mol}$ glutamine $1^{-1}$, and combined antibiotics, and grown to about $80 \%$ confluency in $150 \mathrm{~cm}^{3}$ tissue culture flasks.

\section{Membrane preparations}

Membranes from liver, testis and epididymis were prepared for adrenal cortex by the method of Culty (1984) and adapted for the above tissues by Suarez-Quian \& Niklinski (I990). The tissues were first minced as finely as possible with scissors and washed and homogenized in homogenizing buffer $\left(10 \mathrm{mmol}\right.$ Tris- $-\mathrm{HCl}^{-1}, 2 \mathrm{mmol} \mathrm{EGTA}{ }^{-1}, 0 \cdot 25 \mathrm{~mol}$ sucrose $1^{-1}, \mathrm{pH} 7$-4) using a Polytron homogenizer (Brinkmann Industries, Westbury, NY) for $30 \mathrm{~s}$. The homogenate was centrifuged at $800 \mathrm{~g}$ for $10 \mathrm{~min}$, at $10000 \mathrm{~g}$ for $15 \mathrm{~min}$ and at $100000 \mathrm{~g}$ for $40 \mathrm{~min}$, collecting the supernatant each time for the subsequent centrifugation. The resulting pellet was suspended in a buffer containing $50 \mathrm{mmol} \mathrm{Tris}-\mathrm{HCl}^{-1}$, 5 mmol EGTA $~^{-1}, \mathrm{I} \mathrm{mmol} \mathrm{PMSF}^{-1}(\mathrm{pH} \mathrm{7.4)}$. Membranes from A431 cells were also prepared in this manner. Protein concentration in these preparations was determined using the Bio-Rad Protein Determination Kits (Bradford, 1976).

\section{Western blot}

Solubilized membrane proteins $(20-30 \mu \mathrm{g})$ were separated in $7.5 \%$ acrylamide gels by polyacrylamide gel electrophoresis (PAGE) (Laemmli, 1970) in a Bio-Rad Mini Protean II dual slab gel chamber system (Bio-Rad, 


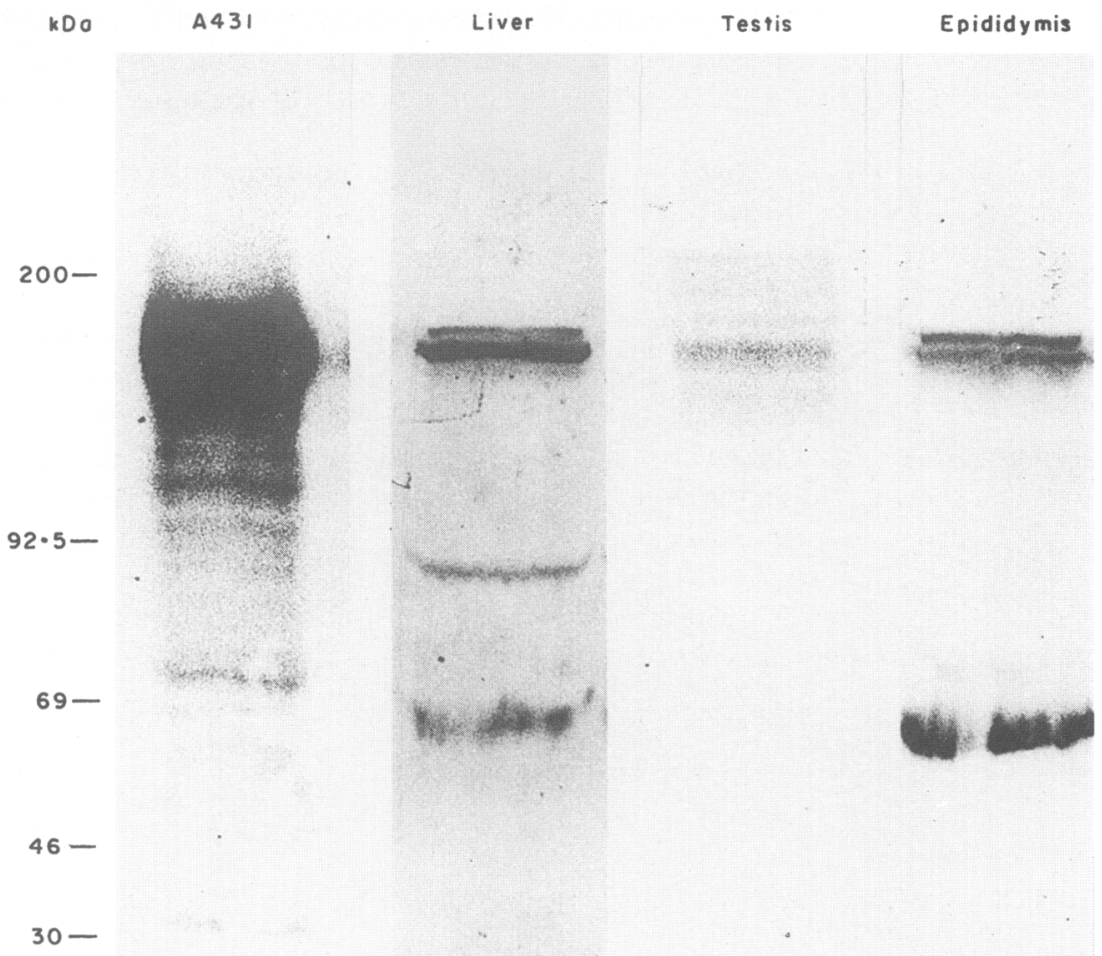

Fig. 1. Immunoblotting of epidermal growth factor receptor (EGFR) with RK2 antibody. Membrane preparations of A431 cells, primate liver, testis and epididymis were separated by $7.5 \%$ PAGE, transferred to nitrocellulose and immunoblotted for EGFR. The prominent band of A431 cells, which overexpresses EGFR, and that of liver (positive controls), corresponding to $170 \mathrm{kDa}$, represent EGFR. The testis and epididymis exhibit corresponding bands, but much lower amounts, indicating the presence of EGFR.

Richmond, CA). After the proteins were transferred onto a nitrocellulose membrane using a Bio-Rad Mini Trans Blot Electrophoretic Transfer Cell, immunoblotting was carried out as described by Burnett (1981) using nonfat dry milk (Johnson et al., 1984) in the following order: incubation of the nitrocellulose membrane with $5 \%$ nonfat milk in phosphate-buffered saline (PBS) containing $0.02 \%$ sodium azide overnight; incubation with primary antibody (RK2 $1: 500$ ) for $\mathbf{l} \mathrm{h}$ at room temperature; treatment with $2.5 \%$ milk in PBS plus $0.1 \%$ Triton $\mathrm{X}-100$; wash with $2.5 \%$ milk in PBS; incubation with secondary antibody (horseradish peroxidase conjugated donkey anti-rabbit antibody diluted $1: 300$ with $2.5 \%$ milk in PBS) for $1 \mathrm{~h}$; repeat washings as before; finally incubation with substrate chromogen mixture (hydrogen peroxide-aminoethyl carbazol). Membrane preparations from A431, the cell line used as the EGF receptor antigen source, were used as positive controls to determine the specific band recognized by the RK2 antibody. In addition we used membrane preparations from livers of male primates, as a positive control tissue source, since the liver is a prominent source of EGF receptors (O'Keefe et al., 1974) with male livers having twice the numbers of EGF receptors as the female liver (Kashimata et al., 1988).

\section{Immunocytochemistry}

The biotin-streptavidin-peroxidase immunocytochemical staining, a direct and sensitive method of antigen detection, was used to demonstrate the distribution of EGF receptors in testis, epididymis and vas deferens. In this immunostaining technique a positive reaction is characterized by a reddish brown reaction product. The primate liver was used as a positive control for the immunostaining procedure, since previous studies in rodents (Dunn et al., 1986) have demonstrated prominent immunostaining of EGF receptor in this tissue in a characteristic pattern. Frozen 

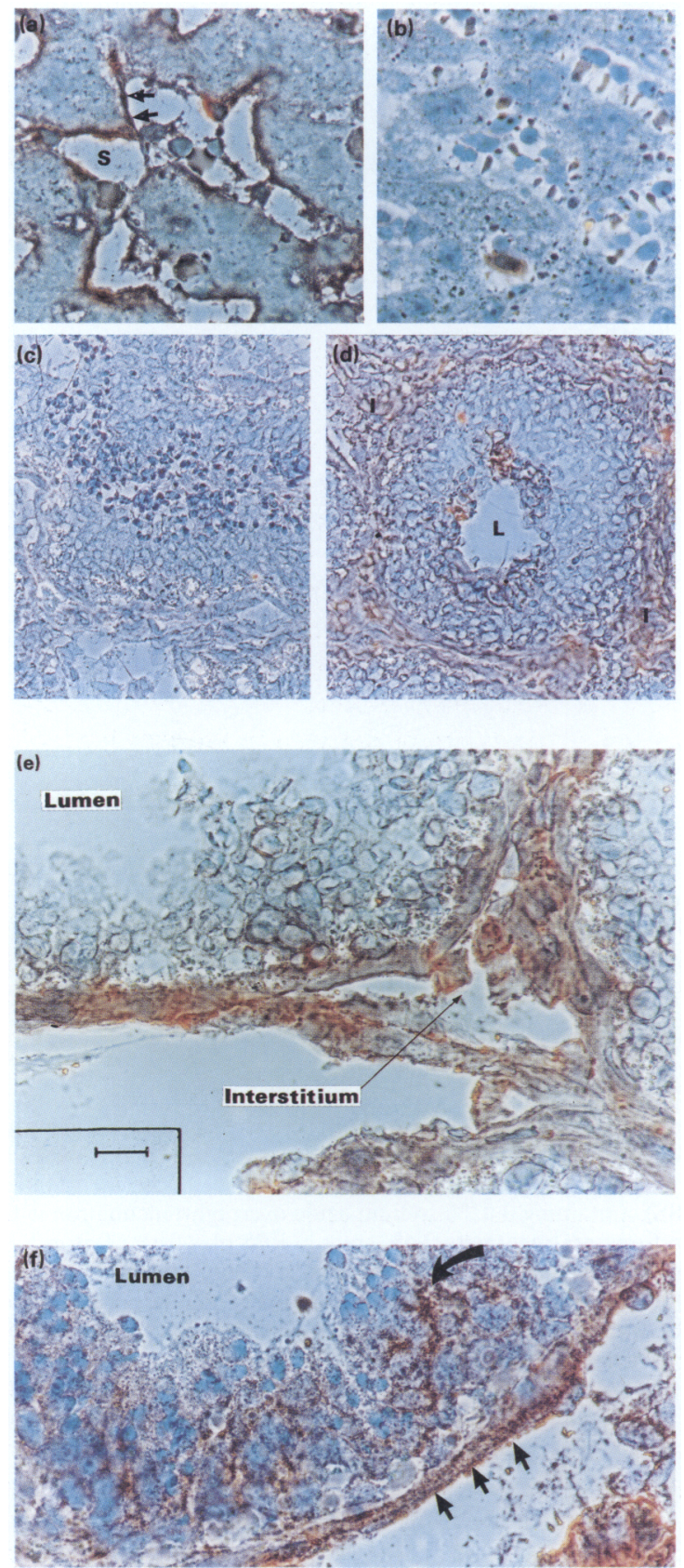
sections, $5-7 \mu \mathrm{m}$ thick, were cut from liver, testis, epididymis and vas deferens using a Reichert-Jung 2000E cryostat. The sections were fixed in $3.7 \%$ formaldehyde for $10 \mathrm{~min}$, permeabilized with $0.1 \%$ Triton X-100 for $45 \mathrm{~s}$ and washed with PBS several times. The immunostaining was then carried out using Histostain-SP Kits (Zymed Laboratories, Burlingame, CA) as described by Suarez-Quian \& Niklinski (1990). Briefly, endogenous peroxidase activity was blocked by a $45 \mathrm{~s}$ treatment with periodic acid solution (Zymed) and endogenous avidin and biotin were blocked using the commercially available avidin and biotin blocking solutions (Zymed) per manufacturer's instructions, followed by blocking nonspecific antibody binding with $10 \%$ nonimmune goat serum, incubated with either pre-immune serum or RK2 antibody (diluted 1:400), and immunostained using biotinylated goat anti-rabbit antibody, streptavidinperoxidase and substrate-chromogen mixture. The sections were then counterstained with haematoxylin and examined with a Zeiss, Planapo $63 \times$ phase $3,1.4$ N.A. objective using an $80 \mathrm{~A}$ blue filter and images recorded on Kodacolor 100 ASA film. Photographs were processed by a professional photographic laboratory (CPI, Bethesda, MD).

\section{Results}

\section{Immunoblotting}

The expression of EGF receptors by A431 cells is represented by the prominent band which corresponds to approximately $170 \mathrm{kDa}$, the molecular mass of EGF receptor, as discerned from the molecular weight standards (Fig. 1). The liver exhibits a band in the corresponding region. The reproductive tissues, the testis and epididymis, exhibit bands that correspond to those of the controls viz., A431 cells and liver. Not enough vas deferens tissue was available to perform a similar experiment. These results demonstrate the presence of EGF receptors in testis and epididymis and ascertain the validity of the RK 2 antibody as a probe for the EGF receptor in non-human primates. The doublet observed in the epididymis lane was consistently found in all preparations, and may represent differential glycosylation in this tissue. The prominent band observed at approximately $60 \mathrm{kDa}$ probably represents a breakdown product of the EGF receptor that is detected in membrane preparations. Similar bands can be detected in Western blots of A431 cell membranes.

\section{Immunostaining}

In primates, the EGF receptors were distributed on the basolateral membranes of hepatocytes lining the liver sinusoids (Fig. 2a). This reaction product was conspicuously absent from the preimmune treated liver section (Fig. 2b). The cells of the haemopoietic system were devoid of EGF receptors and so were the erythrocytes in liver sections (Fig. 2b). The pre-immune treated testis sections were devoid of any positive staining for EGF receptors (Fig. 2c).

The testis sections showed the distribution of EGF receptors in Sertoli cells, peritubular cells (Fig. $2 \mathrm{~d}$ and e) and in the interstitium. At higher magnification, the interstitial reaction product was clearly detected in Leydig cells. The testis sections treated with RK2 antibody showed the reaction

Fig. 2. Epidermal growth factor receptor (EGFR) immunostaining in primate testis. As a positive control for biotin-streptavidin peroxidase immunocytochemistry, frozen sections of primate livers were immunostained with (a) RK2 antisera or (b) pre-immune sera. Reddishbrown immunostain represents cell site of specific immunoreactivity. Sections were counterstained with haematoxylin which produced the blue stain of the nuclei. In (a) liver, specific EGFR immunoreactivity was detected in the basolateral membrane (arrows) of cells lining the sinusoids (S), and red blood cells were devoid of staining. In testis, EGFR immunostaining using (c) either pre-immune sera as control, or (d) RK2 antisera, observed at low magnification are shown. In (d) prominent immunostaining is detected in the interstitial area (I), most likely corresponding to Leydig cells (L), and to the boundary cells of the seminiferous tubules, the peritubular cells, although seminiferous epithelium EGFR immunostaining was not apparent in all tubule cross-sections. In (e) the Leydig cell EGFR immunostaining is more apparent. At higher magnification (f), prominent EGFR immunostaining can be detected (curved arrow) in the seminiferous epithelium, corresponding to Sertoli cells, as well as in peritubular cells (short arrows). Magnification (a), (b) and (f) $\times 460$; (c) and (d) $\times 180$; (e) $\times 560$. 


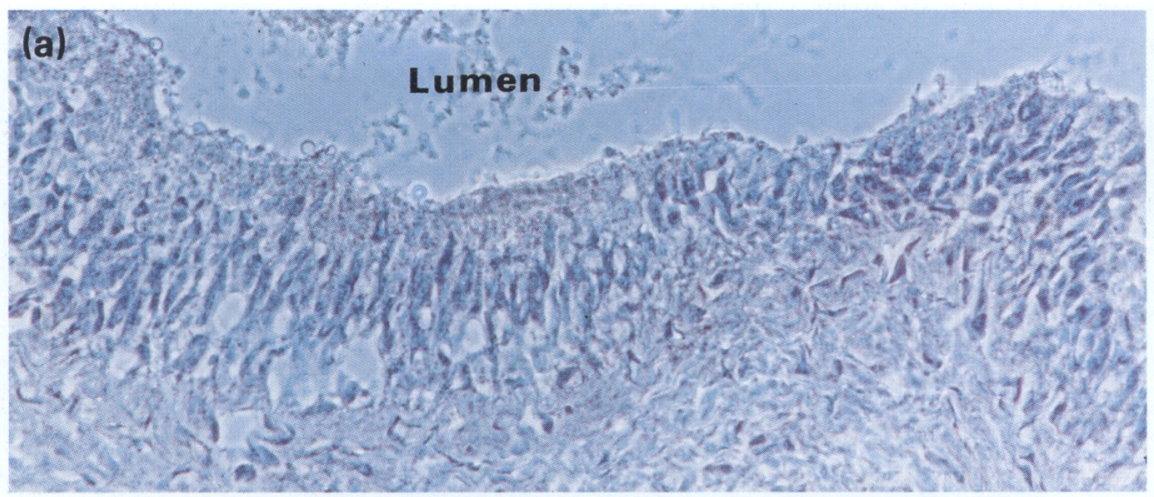

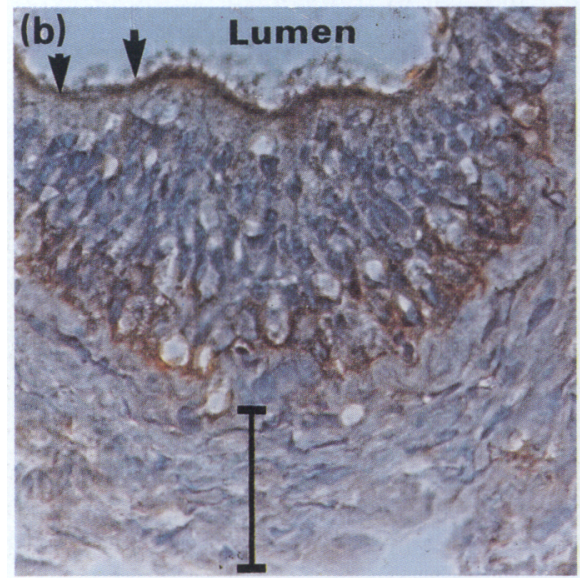

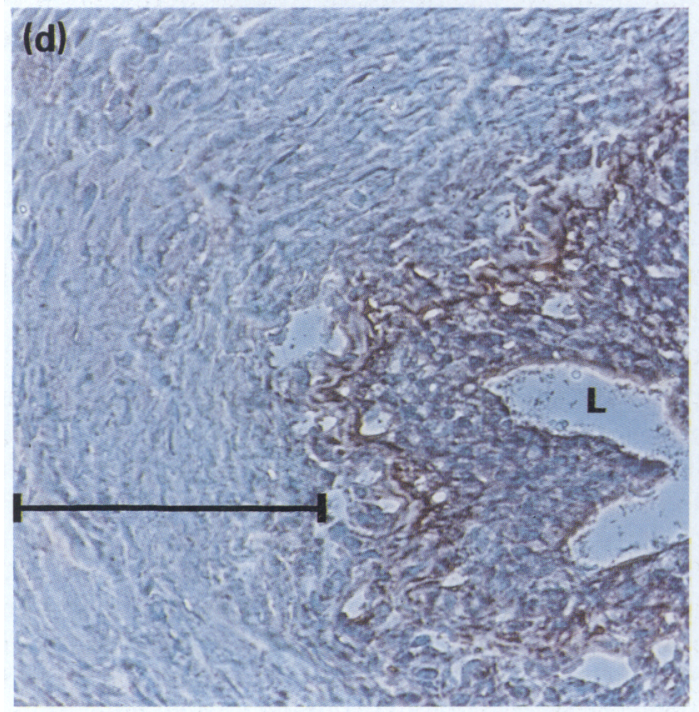

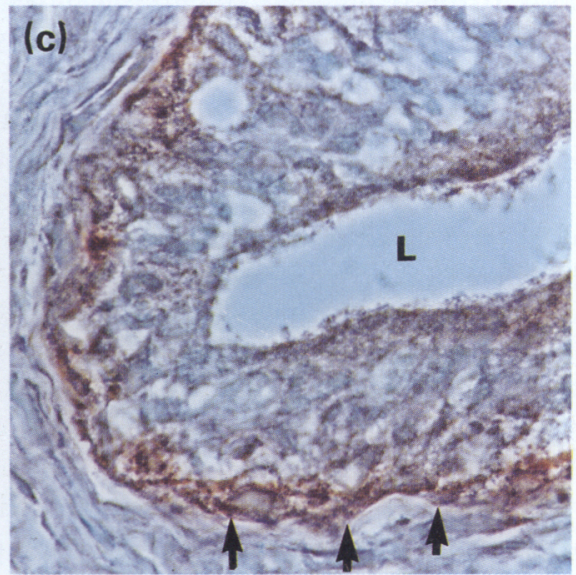

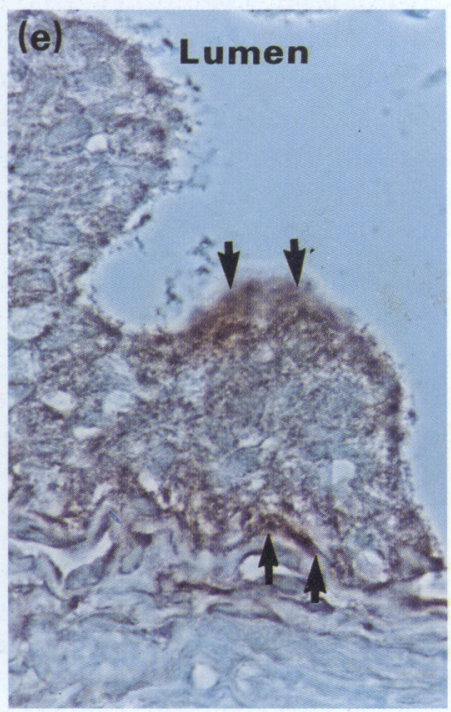


product as incursions of reddish brown colour into seminiferous tubules in a pattern consistent with the area known to be occupied by Sertoli cells. The peritubular cells which form the boundary tissue of the seminiferous tubules, as well as cells in the interstitium, also exhibited a prominent reaction product.

The EGF receptor distribution in the epididymis was observed on the basolateral and luminal borders of the epithelial cells lining the ductus epididymidis. The pre-immune treated epididymal sections were negative (Fig. 3a). However, the smooth muscle layers of the duct were devoid of EGF receptor staining (Fig. $3 b$ and c). The pattern of immunostaining in vas deferens was quite similar to that observed in the epididymis; immunostaining was prominent on the basolateral and luminal borders of the epithelial cells lining the ductus deferens ( $3 \mathrm{~d}$ and $\mathrm{e}$ ). As in the epididymis, none of the smooth muscle layers in vas deferens showed any positive immunostaining.

The distribution of the EGF receptors in the epididymis of pubertal monkeys was also determined. Using this technique a similar distribution of EGF receptors was observed in the epididymis, both basolateral and luminal immunostaining was prominent (Fig. 4). Specifically, the luminal immunostaining pattern was clearly vesicular and was consistent with an immunostaining pattern recognizing compartments of the receptor-mediated endocytic system.

\section{Discussion}

The distribution of EGF receptors in testes, epididymides and vasa deferentia of the non-human primate was investigated. Immunoblotting of membrane preparations from testes and epididymides demonstrated that a specific band of $170 \mathrm{kDa}$ was detected and served to validate the RK2 antibody as a probe for the EGF receptor in non-human primates. The A431 cells, used as positive controls, overexpress EGF receptors on the cell surface by 20-50 fold (Carpenter, 1987) and the prominent $170 \mathrm{kDa}$ band is a characteristic feature of immunoblots obtained with this cell type. Similarly, the liver, which is also rich in EGF receptors, gave rise to a prominent band at $170 \mathrm{kDa}$ by immunoblotting. In contrast, membrane preparations from testis gave rise to a less robust band at $170 \mathrm{kDa}$ which appears to be consistent with the immunostaining results. That is, positive immunostaining was observed only in the somatic components of the testis. Since the germinal component comprises most of the mass of the adult testis, and membrane preparations were composed of both somatic and germ cells, we interpret the faint $170 \mathrm{kDa}$ band as specific, but containing numbers of EGF receptors that are barely detectable by immunoblotting.

Immunostaining of adult primate testis with RK2 antibody demonstrated the presence of the distribution of EGF receptors on Sertoli cells, Leydig cells and peritubular cells. These results suggest that if EGF is to exert an effect on spermatogenesis, then the effects will be mediated indirectly via the somatic components of the testis. These observations are consistent with previous studies in rodents that demonstrated immunoreactive EGF receptors in Sertoli cells and Leydig cells (Suarez-Quian et al., 1989; Suarez-Quian \& Niklinski, 1990). However, a marked difference was observed between the primate and rodent testis; peritubular cells of primates also exhibited prominent EGF receptor immunostaining. The significance of this different EGF receptor immunolocalization is not clear, although previous studies of rat peritubular cells in vitro reported that they respond to EGF (Skinner et al., 1989).

Fig. 3. Epidermal growth factor receptor (EGFR) immunostaining in epididymis and vas deferens. (a) Preimmune control sections of epididymis are shown. EGFR immunostaining with RK2 antisera in (b) and (c) epididymis and (d) and (e) vas deferens are shown. In (c) the lumen (L) of the epididymis is labelled. Both tissues demonstrate basolateral and apical EGFR immunostaining (arrows) in cells forming the epithelium. Note absence of immunostaining in the smooth muscle cells (area demarcated by black lines) forming the boundary layer of both ducts. Magnification (a), (b), (d) $\times 300$; (c) and (e) $\times 740$. 

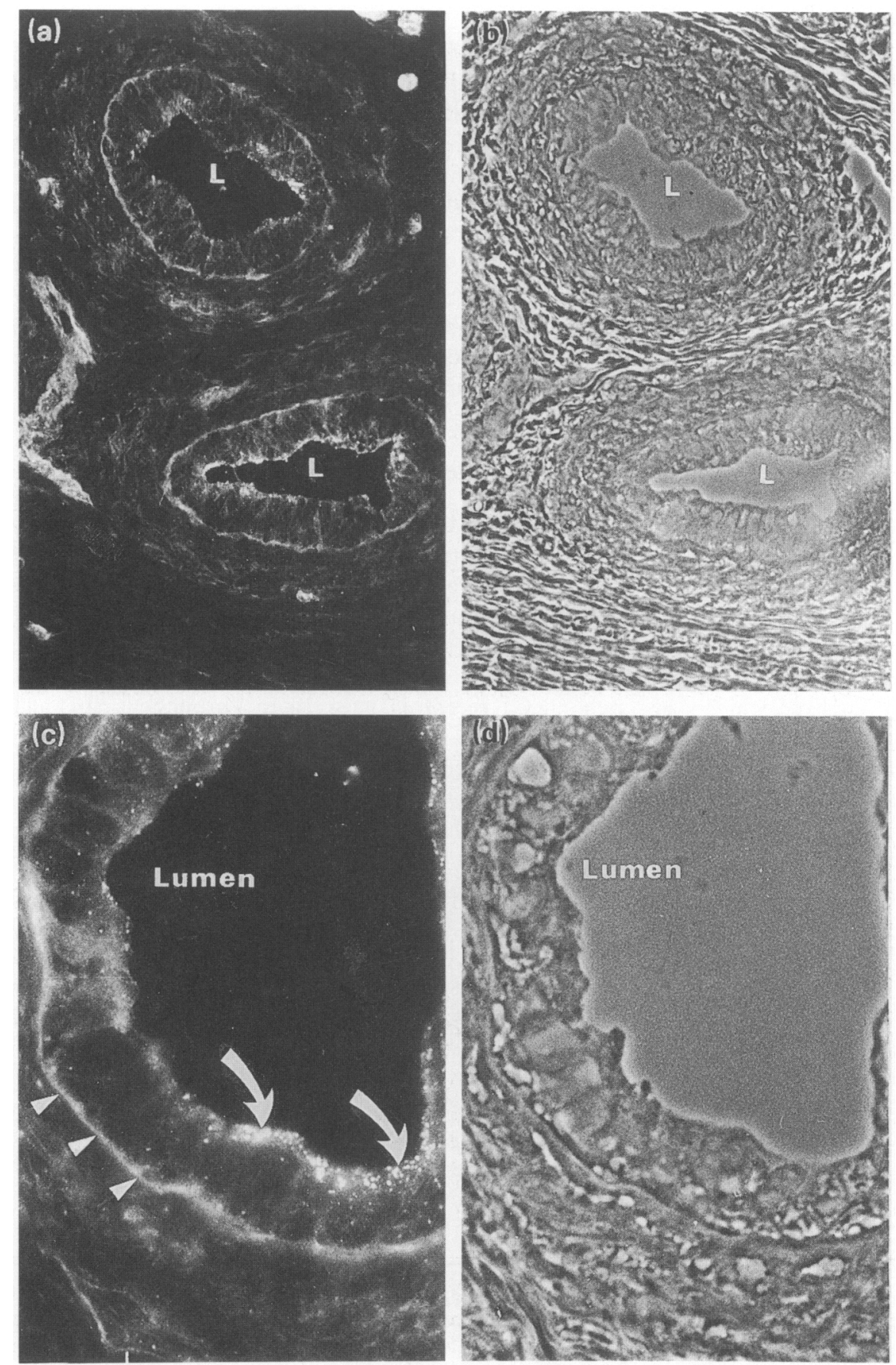
Since epidermal growth factor was first isolated (Cohen, 1962), its role as a potent mitogen for various cells (reviewed in Carpenter \& Cohen, 1979; Gospodarowicz, 1981), as well as for certain endocrine cell lines (reviewed in Fisher \& Lakshmanan, 1990) has been reported. Consequently, EGF receptor immunolocalization in testicular somatic components that may not undergo cell division after puberty represents an apparent paradox. Other studies, however, have also demonstrated immunoreactive EGF receptors in terminally differentiated tissues, e.g. various cells of the nervous system (Werner et al., 1988). Furthermore, EGF has been shown to serve as a 'differentiation' factor, rather than a mitogen, in several nondividing cells. For example, EGF can stimulate growth hormone secretion from anterior pituitary cells (Ikeda et al., 1984; Kudlow \& Kobrin, 1984) and prolactin secretion (Johnson et al., 1980). Similarly, the EGF receptor immunostaining described in this study is consistent with previous functional studies in rat Sertoli cells and Leydig cells in vitro. That is, EGF has been shown to exert effects on Sertoli cells, especially on their primary capacity as nurse cells for germ cells. Modulation of androgen-binding protein secretion (Rich et al., 1983), stimulation of lactate production (Mallea et al., 1986), and production of inhibin (Morris et al., 1988) appear to be partly under EGF control. The effects of EGF on gonadal steroid production in males include inhibition of aromatization by Sertoli cells in vitro (Mallea et al., 1986), diminution of human chorionic gonadotrophin (hCG)-binding sites on Leydig cells (Ascoli, 1981) and inhibition of hCG-stimulated testosterone production by Leydig cells in vitro (Welsh \& Hsueh, 1982), although a later report described a stimulatory effect of EGF in the presence of gonadotrophins (Verhoeven \& Cailleau, 1986) which has been shown to be mediated by increasing the availability of cholesterol substrate (Sordoillet et al., 1991). Although there are no similar functional studies of EGF effects on primate Sertoli and Leydig cells, our results provide the structural basis for which parallel investigations should be pursued.

The presence of EGF receptors in epididymides is particularly significant since it is a site of maturation of spermatozoa (reviewed in Robaire \& Hermo, 1988). The distribution of EGF receptors in epididymides and vasa deferentia, i.e. along the basolateral and luminal borders of the epithelial cells, presents interesting possibilities as to the source of EGF for these tissues: EGF, or an EGF-like molecule that exploits the EGF receptor, could be derived from either the seminiferous tubules or the plasma. Once bound to the cell surface localized receptor, the EGF would elicit its intracellular signal and then become internalized and degraded in lysosomes. It is this pathway that is commonly encountered in other EGF-EGF receptor systems (Carpenter, 1987). Alternatively, the presence of the EGF receptor in both the apical and basal surfaces of the epididymal cells suggests that EGF is transcytosed across the epithelium. For example, one study in Madin Darby canine kidney cells in vitro (which create a permeability barrier when grown in two compartment chambers) reported that EGF was transcytosed from the basolateral membrane, where EGF receptors are found in these cells, to the apical media (Maratos-Flier et al., 1987). In contrast, although our interpretation is not definitive, the immunofluorescence data demonstrating vesicular structures akin to coated vesicles and endosomes along the apical borders of the epididymal principal cells favour the suggestion of a luminal EGF. In this regard EGF has been detected in human seminal fluid and in tissue homogenates from testis and epididymis (Elson $e t$ al., 1984); an EGF-like molecule was identified in culture media from mouse and human Sertoli cells (Holmes et al., 1986; Buch et al., 1988); and transforming growth factor alpha (TGF- $\alpha$ ) has been immunolocalized in adult rat testis (Teerds et al., 1990). Similarly, non-human primates should

Fig. 4. Epidermal growth factor receptor (EGFR) localization in caput epididymis by immunofluorescence. Frozen sections of epididymis were prepared as described in legend to Fig. 3 and immunostained for EGFR, except that localization was performed using immunofluorescence. Corresponding phase images of fluorescence profiles (a) and (c) are shown in (b) and (d), respectively. Note that basolateral (triangles) and apical (arrows) EGFR immunostaining is also observed using this technique. In addition, the vesicular nature of the apical immunostaining is readily apparent. Magnification (a), (b) $\times 180$; (c), (d) $\times 400$. 
be investigated to determine whether they also produce an EGF or EGF-like growth factor that may travel downstream to the epididymides where it may be internalized by receptor-mediated endocytosis. Regardless of the path travelled by EGF in the epididymis and vas deferens, the presence of EGF receptors in these tissues suggest further studies on the potential role of EGF in the functions of epididymis and vas deferens.

Our studies indicate the cell sites of action of EGF in primate testis and epididymis; the potential role of EGF in production and maturation of spermatozoa in primates warrants new venues for investigations in fertility and infertility control in man.

\section{This work was funded in part by NIH Grant no. HD 23484 to C. A. Suarez-Quian.}

\section{References}

Ascoli, M. (1981) Regulation of gonadotropin receptors and gonadotropin responses in a clonal strain of Leydig tumor cells by epidermal growth factor. Journal of Biological Chemistry 256, 179-183.

Bartlett, J.M., Spiteri-Grech, J. \& Nieschlag, E. (1990) Regulation of insulin-like growth factor I and stagespecific levels of epidermal growth factor in stage synchronized rat testes. Endocrinology 127, 747-758.

Bellot, F., Moolenaar, W., Kris, R., Mirakhur, B., Verlaan, I., Ullrich, A., Schlessinger, J. \& Felder, S. (1990) High-affinity epidermal growth factor binding is specifically reduced by a monoclonal antibody and appears necessary for early responses. Journal of Cell Biology 110, 491-502.

Bellve, A.R. \& Zheng, W. (1989) Growth factors as autocrine and paracrine modulators of male gonadal function. Journal of Reproduction and Fertility 85, $771-793$

Bernier, M., Chatelain, P., Mather, J.P. \& Saez, J.M. (1986) Regulation of gonadotropin receptors, gonadotropin responsiveness, and cell multiplication by somatomedin-C and insulin in cultured pig Leydig cells. Journal of Cell Physiology 129, 257-263.

Bradford, M.M. (1976) A rapid and sensitive method for the quantitation of microgram quantities of protein using the principle of protein dye binding. Analytical Biochemistry 72, 248-254.

Buch, J.P., Lamb, D.J., Lipshultz, L.I. \& Smith, R.G. (1988) Partial characterization of a unique growth factor secreted by human Sertoli cells. Fertility and Sterility 49, 658-665.

Burnett, W.N. (1981) Western blotting: electrophoretic transfer of proteins from sodium dodecyl sulfatepolyacrylamide gels to unmodified nitrocellulose and radiographic detection with antibody and radioiodinated proteins. Journal of Analytical Biochemistry 112, 195-203.

Carpenter, G. (1987) Receptors for epidermal growth factor and other polypeptide mitogens. Annual Review's of Biochemistry 56, 881-914.

Carpenter, G. \& Cohen, S. (1979) Epidermal growth factor. Annual Review's of Biochemistry 48, 193-216.

Cohen, S. (1962) Isolation of a mouse submaxillary gland protein accelerating incisor eruption and eyelid opening in the newborn animal. Journal of Biological Chemistry 273, 1555-1562.

Culty, M. (1984) Phosphoinositide metabolism and steroidogenesis of adrenal cortex. PhD Thesis, Université Scientifique et Medicale de Grenoble, France.
Dunn, W.A., Connolly, T.P. \& Hubbard, A.L. (1986) Receptor-mediated endocytosis of epidermal growth factor by rat hepatocytes: receptor pathway. Journal of Cell Biology 102, 24-36.

Elson, S.D., Browne, C.A. \& Thorburn, G.D. (1984) Identification of epidermal growth factor-like activity in human male reproductive tissues and fluids. Journal of Clinical Endocrinology and Metabolism 58, 589-594.

Fisher, D.A. \& Lakshmanan, J. (1990) Metabolism and effects of epidermal growth factor and related growth factors in mammals. Endocrine Reviews 11, 418-442.

Gill, G.N., Bertics, P.J. \& Santon, J.B. (1987) Epidermal growth factor and its receptor. Molecular and Cellular Endocrinology 51, 169-186.

Gospodarowicz, D. (1981) Epidermal and nerve growth factors in mammalian development. Annual Reviews of Physiology 43, 251-263.

Holmes, S.D., Spotts, G. \& Smith, R.G. (1986) Rat Sertoli cells secrete a growth factor that blocks epidermal growth factor (EGF) binding to its receptor. Journal of Biological Chemistry 261, 4076-4080.

Ikeda, H., Mitsuhasi, T., Kubota, K., Kuzuya, N. \& Uchimura, H. (1984) Epidermal growth factor stimulates growth hormone secretion from superfused rat adenohypophysial fragments. Endocrinology 115, $556-558$.

Johnson, D.A., Gautsch, J.W., Sportsman, J.R. \& Edler, J.H. (1984) Improved technique utilizing nonfat dry milk for analysis of proteins and nucleic acid transferred to nitrocellulose. Gene Analytical Technique 1, $13-18$.

Johnson, L.K., Baxter, J.D., Vlodavsky, I. \& Gospodarowicz, D. (1980) Epidermal growth factor and expression of specific genes: effects on cultured rat pituitary cells are dissociable from the mitogenic response. Proceedings of the National Academy of Sciences USA 77, 394-398.

Kashimata, M., Hiramatsu, M. \& Minami, N. (1988) Sex difference in epidermal growth factor receptor levels in rat liver plasma membrane. Endocrinology 122, $1707-1714$.

Keeping, H.S. (1991) Differential regulation of testicular growth factor receptor gene expression during sexual development in the cynomolgus monkey. Journal of Andrology Supplement 12, 26.

Kris, R.M., Lax, I., Gullick, W., Waterfield, M.D. Ullrich, A., Fridkin, M. \& Schlessinger, J. (1985) Antibodies against a synthetic peptide as a probe 
for the kinase activity of the avian EGF receptor and v-erbB protein. Cell 40, 619-625.

Kudlow, J.E. \& Kobrin, M.S. (1984) Secretion of epidermal growth factor-like mitogens by cultured cells from bovine anterior pituitary glands. Endocrinology 115, 911-917.

Laemmli, U.K. (1970) Cleavage of structural proteins during assembly of the head of bacteriophage T4. Nature 227, 680-685.

Mallea, L.E., Machado, A.J., Navaroli, F. \& Rommerts, F.F.G. (1986) Epidermal growth factor stimulates lactate production and inhibits aromatization in cultured Sertoli cells from immature rats. International Journal of Andrology 9, 201-208.

Maratos-Flier, E., Kao, C-Y.Y., Verdin, E.M. \& King, G.L. (1987) Receptor-mediated vectorial transcytosis of epidermal growth factor by Madin-Darby canine kidney cells. Journal of Cell Biology 105, 1595-1601.

Morris, P.L., Vale, W.W., Cappel, S. \& Bardin, C.W. (1988) Inhibin production by primary Sertoli cellenriched cultures: regulation by follicle-stimulating hormone, androgens, and epidermal growth factor. Endocrinology 122, 717-725.

Noguchi, S., Ohba, Y. \& Oka, T. (1990) Involvement of epidermal growth factor deficiency in pathogenesis of oligozoospermia in streptozotocin-induced diabetic mice. Endocrinology 127, 2136-2140.

O'Keefe, E., Hollenberg, M.D. \& Cuatrecasas, P. (1974) Epidermal growth factor: characteristics of specific binding in membranes from liver, placenta, and other target tissues. Archives of Biochemistry and Biophysics 164, 518-526.

Rich, K.A., Bardin, C.W., Gunsalus, G.L. \& Mather, J.P. (1983) Age-dependent pattern of androgen-binding protein secretion from rat Sertoli cells in primary culture. Endocrinology 113, 2284-2293.

Robaire, B. \& Hermo, L. (1988) Efferent ducts, epididymis, and vas deferens: structure, functions, and their regulation. In The Physiology of Reproduction, pp. 999-1080. Eds E. Knobil \& J. Neill. Raven Press, New York.

Russell, L.D., Weiss, T., Goh, J.C. \& Curl, J.L. (1990) The effects of sialoadenectomy (submandibular gland removal) on testicular and epididymal parameters. Tissue and Cell 22, 263-268.

Schlessinger, J. (1986) Allosteric regulation of the epidermal growth factor receptor kinase. Journal of Cell Biology 103, 2067-2072.

Seethalakshmi, L., Liu, L., Kinkead, T., Flores, C. Carboni, A.A., Menon, M. \& Davis, R. (1991) Epidermal growth factor (EGF): an important role in testicular function. Journal of Andrology Supplement p. 60.

Skinner, M.K. (1991) Cell-cell interactions in the testis. Endocrinology Reviews 12, 45-77.
Skinner, M.K., Takacs, K. \& Coffey, R.J. (1989) Transforming growth factor- $\alpha$ gene expression and action in the seminiferous tubule: peritubular cellSertoli cell interactions. Endocrinology 124, 845-854.

Smith, F.F., Tres, L.L. \& Kierszenbaum, A.L. (1987) Ornithine decarboxylase activity during rat spermatogenesis in vivo and in vitro: selective effect of hormones and growth factors. Journal of Cell Physiology 133, 305-312.

Sordoillet, C., Chauvin, M.A., de Peretti, E., Morera, A.M. \& Benahmed, M. (1991) Epidermal growth factor directly stimulates steroidogenesis in primary cultures of porcine Leydig cells: actions and sites of action. Endocrinology 128, 2160-2168.

Suarez-Quian, C.A. \& Niklinski, W. (1990) Immunocytochemical localization of the epidermal growth factor receptor in mouse testis. Biology of Reproduction 43, 1087-1097.

Suarez-Quian, C.A., Dai, M., Onoda, M., Kris, R.M. \& Dym, M. (1989) Epidermal growth factor receptor localization in the rat and monkey testes. Biology of Reproduction 41, 921-932.

Teerds, K.J., Rommerts, F.F.G. \& Dorrington, J.H. (1990) Immunohistochemical detection of transforming growth factor- $\alpha$ in Leydig cells during the development of the rat testis. Molecular and Cellular Endocrinology 69, R1-R6.

Tsutsumi, O., Kurachi, H. \& Oka, T. (1986) A physiological role of epidermal growth factor in male reproductive function. Science $\mathbf{2 3 3 , 9 7 5 - 9 7 7 . ~}$

Ullrich, A., Coussens, L., Hayflick, J.S., Dull, T.J., Gray, A., Tam, A.W., Lee, J., Yarden, Y., Libermann, T.A., Schlessinger, J., Downward, J., Mayes, E.L.V., Whittle, N., Waterfield, M.D. \& Seeburg, P.H. (1984) Human epidermal growth factor receptor cDNA sequence and aberrant expression of the amplified gene in A431 epidermoid carcinoma cell. Nature $309,418-425$.

Verhoeven, G. \& Cailleau, J. (1986) Stimulatory effects of epidermal growth factor on steroidogenesis in Leydig cells. Molecular and Cellular Endocrinology 47, 99-106.

Welsh, T.H. \& Hsueh, A.J.W. (1982) Mechanism of the inhibitory action of epidermal growth factors on testicular androgen biosynthesis in vitro. Endocrinology 110, 1498-1506.

Werner, M.H., Nanney, L.B., Stoscheck, C.M. \& King, L.E. (1988) Localization of immunoreactive epidermal growth factor receptors in human nervous system. Journal of Histochemistry and Cytochemistry 36, $8 \mathrm{I}-86$.

Received 28 May 1991 